\begin{tabular}{|l|l|l||}
\hline \multicolumn{2}{|c|}{ PublisherInfo } \\
\hline \hline PublisherName & $:$ & BioMed Central \\
\hline \hline PublisherLocation & $:$ & London \\
\hline \hline PublisherImprintName & $:$ & BioMed Central \\
\hline \hline
\end{tabular}

Hox: total knockout

\begin{tabular}{|l|l|l||}
\hline \multicolumn{2}{|c|}{ ArticleInfo } \\
\hline \hline ArticleID & $:$ & 4815 \\
\hline \hline ArticleDOI & $:$ & $10.1186 /$ gb-spotlight-20030718-01 \\
\hline \hline ArticleCitationID & $:$ & spotlight-20030718-01 \\
\hline \hline ArticleSequenceNumber & $:$ & 167 \\
\hline \hline ArticleCategory & $:$ & Research news \\
\hline ArticleFirstPage & $:$ & 1 \\
\hline \hline ArticleLastPage & $:$ & 2 \\
\hline \hline & & RegistrationDate : 2003-7-18 \\
\hline ArticleHistory & $:$ & OnlineDate \\
\hline \hline ArticleCopyright & $:$ & BioMed Central Ltd2003-7-18 \\
\hline \hline ArticleGrants & $:$ & \\
\hline \hline ArticleContext & $:$ & 130594411 \\
\hline \hline
\end{tabular}




\section{Cathy Holding}

Email: cholding@hgmp.mrc.ac.uk

The most primitive skeletal pattern consists of ribs projecting from vertebrae, from the head through to the tail. In mice, ribs are restricted to the thoracic region, and the axial skeleton consists of seven cervical, 13 thoracic, six lumbar, four sacral, and a variable number of caudal vertebrae. Hox genes control the patterning of the skeleton, but exactly how they achieve this has been confused by the redundant function of genes within the four chromosomal linkage groups, A-D, which arose during evolution by genomic duplication events. In the July 18 Science, Deneen M. Wellick and Mario R. Capecchi at the Howard Hughes Medical Institute clarify our understanding of skeletal development by knocking out each redundant copy in two of 13 paralogous sets of Hox genes. This reveals that these genes interact with one another in repressing the basic primitive skeletal pattern (Science 2003, 301:363-367).

Wellick and Capecchi introduced mutations in Hox 10a, Hox10c, and Hox10d genes, and separately in Hox 11a, Hox11c, and Hox11d genes. They compared the effects when all six alleles of Hox10 or Hox11 were knocked out against any five of the six alleles to show the extent of redundancy of function in these genes. Hox 10 paralogous genes suppressed thoracic development posterior to the 13th thoracic vertebra, and Hox 11 paralogous genes positively regulated the formation of sacral vertebrae by partially suppressing Hox 10 function in that region. In addition, together with previous data, they propose that combinations of expression of Hox paralogous groups 9-13 govern the pattern of development of the fore- and hindlimbs.

"Both in the formation of the axial skeleton and in the limbs, all members of a paralogous family that are expressed in a given structure must be disrupted before the full nature of the mutant phenotype is realized. By removing the redundancy in this system, we are beginning to understand the fundamental role these genes play in patterning the vertebrate skeleton," the authors conclude.

\section{References}

1. Hox genes and morphological identity: axial versus lateral patterning in the vertebrate mesoderm

2. Arthropod Hox genes: insights on the evolutionary forces that shape gene functions

3. Science, [http://www.sciencemag.org/]

4. Howard Hughes Medical Institute, [http://www.hhmi.org/] 